\title{
John 21:24-25: A case of failed attestation?
}

D F Tolmie

\section{ABSTRACT}

\section{John 21:24-25: A case of failed attestation}

In this article the tendency to interpret John 21:24-25 narratologically as a highly sophisticated and effective technique is disputed. Instead it is argued that the Beloved Disciple is identified in these verses as the real author of the Gospel and that the dominating function in John 21:24-25 is the testimonial function (also known as the function of attestation). It is also argued that the intended effect of this function is undermined by the awkward manner in which it is fulfilled.

The Fourth Gospel ends as follows:

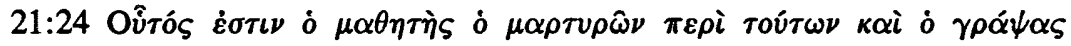

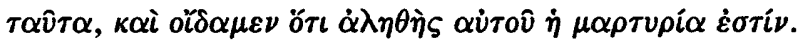

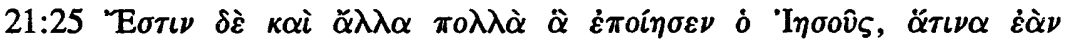

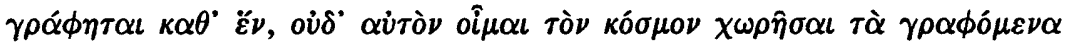
$\beta \iota \beta \lambda i \alpha$.

Traditionally, these last two verses have been used (together with John 19:35) as a basis for arguments on the authorship of the Fourth Gospel. As all New Testament scholars will know, no consensus has been reached in this regard, and opinions vary from interpretations that take these two verses as an indication that the whole Gospel had been written by one person (usually identified as John, the Son of Zebedee ${ }^{1}$ ) to those that regard them as an addition at a later editorial stage ${ }^{2}$. It is not my intention to open this discussion again. Instead I wish to discuss the way in which John 21:24-25 have been interpreted by scholars who follow a narrative critical/narratological approach to the Fourth Gospel. Since the issue of authorship usually does not play a big role in this approach to texts, their attention has mostly been focused on the effect of these two verses in terms of the relationship between the implied author/narrator on the one hand and narratee/implied reader on the other hand. I shall discuss two interpretations that are to my mind the most significant.

In his excellent study on the literary design of the Fourth Gospel, $\mathbf{R}$ Alan Culpepper ${ }^{3}$ discusses John 21:24-25 in a chapter devoted to "narrator 
and point of view". In this chapter he discusses the relationship between the implied author and the Beloved Disciple and, with reference to John 21:24, he argues that the Beloved Disciple is identified by the narrator as the implied author ${ }^{4}$ of the Fourth Gospel:

Not only does the evangelist create a superior version of himself as he writes, but the editor identifies this superior self ("who has written these things") as the Beloved Disciple. When the narrator dramatically pulls the curtain on the implied author in the closing verses of the gospel, the reader recognizes that the Beloved Disciple fits the image the gospel projects of its implied author as one who knows Jesus intimately, shares his theological perspective, and can interpret reliably, that is, "his witness is true".

From this quotation it is also clear how Culpepper views the effect of John 21:24: Together with other devices such as the reliability of the narrator and the words of Jesus about the Paraclete, it is used to establish the authority of the Fourth Gospel, thereby inclining the reader towards accepting the author's understanding of Jesus 5 .

In his book on the implied reader of the Fourth Gospel, Jeffrey Staley ${ }^{6}$ discusses John 19:35 and 21:24-25 in a chapter devoted to the rhetorical levels of discourse in the Gospel. His interpretation differs in two important aspects from that of Culpepper. Firstly, he argues that the Beloved Disciples is identified not as the implied author of the Fourth Gospel, but as the narrator of the Gospel. Secondly, he argues that a very sophisticated technique, the so called "trick of double reference" 7 is used in John 21:24-25. When this device is used, the narrator speaks of himself/herself in the third person ("he/she") when referring to himself/herself as character in the narrative world, but in the first person (" $I$ ") when referring to himself/herself as narrator ${ }^{8}$. With regard to the effect of these two verses Staley9 indicates that the unveiling of the story's narrator as the Beloved Disciple will come as a surprise to the implied reader, but, that in spite of all the questions that remain unanswered, at least, the Beloved Disciple's relationship to the story is settled at the closure of the narrative. With regard to verse 25 , he indicates that it will be "more that mildly disconcerting" 10 to the implied reader since it emphasises the radical selectivity of the narrator.

From this short discussion it is clear that, in spite of the differences between them, both Culpepper and Staley view John 21:24-25 as rather effective in terms of the relationship between implied author/narrator and implied reader. To my mind this is not correct. I shall argue my case in three steps.

Firstly, I wish to point out that the Beloved Disciple is identified neither as the implied author (as Culpepper maintains) nor as the narrator 
(as Staley argues) but as the real author, that is the person who actually wrote the Gospel11. In fact, this is what is claimed in verse 24: Oîं ${ }^{11} \varsigma \dot{\varepsilon} \sigma \tau \iota \nu$

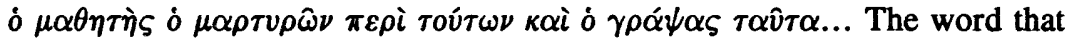
is used is $\gamma \rho \alpha \phi \omega$ - indicating the person who actually wrote the narrative ${ }^{12}$. Of course this claim cannot be accepted in terms of a historical-critical perspective, but it is important to realise that, in working from a narratological perspective, one should interpret these verses purely in terms of a narratological framework and not be influenced by historicalcritical arguments. Purely in terms of a narratological approach what happens in John $21: 24-25$ is that the narrator identifies one of the characters in the narrative, the Beloved Disciple, as the real author of the narrative who actually wrote it himself.

Secondly, although the purpose of verse 24 has been identified correctly by Culpepper as an effort to establish the authority of the Fourth Gospel I would like to point out a better way to describe this aspect in narratological terms. The narratological frame work developed by Gérard Genette can be of use here - especially his remarks with regard to the functions that a narrator may fulfil in a narrative. In his discussion of the role of a narrator in a narrative, Genette ${ }^{13}$ distinguishes between the following five functions that a narrator may fulfil:

* A narrative function, $i$ e by narrating the story.

* A directing function, i e by providing metanarrative articulations, connections and interrelationships.

* A communcative function, $\mathrm{i}$ e by establishing and maintaining contact with the narratee.

* A testimonial function, i e by indicating the relationship $s /$ he has with the narrative.

* An ideological function, $\mathrm{i}$ e by providing authorised commentary on the action.

I would propose that the dominating function in John 21:24-25 is the testimonial function. This function (also called the function of attestation) has to do with the moral or intellectual relationship that the narrator has to his/her story. According to Genette, the narrator may fulfil this function in various ways, for example through indication of the sources of information that s/he uses; by attesting to the truthfulness of his/her sources of information or of the intermediary witnesses; by explaining the degree of precision of his/her memories; or by describing the feelings which one or another of the episodes awakens in him/her. In the case of John 21:24-25 we have an example of the function of attestation in the sense that the narrator attests to the reliability of his narrative by identifying one of the 
characters not only as the reliable source of the information, but actually as the real author of the narrative.

Thirdly, and to my mind this has been missed by both Staley and Culpepper, it is important to realise that the intended effect of the function of attestation is undermined by the awkward way in which it is performed. In order for this function to be effective, it should be performed in such a way that the implied reader ${ }^{14}$ should not have the least doubt that the claim to truthfulness is indeed valid and therefore acceptable. In other words, the function of attestation should be performed in such a way that the implied reader's immediate reaction would be something like the following: "Yes, I believe this narrative as it is evidently based on reliable sources". On the other hand, if there is anything questionable in the way in which this function is performed, it will have the opposite effect, and the implied reader's reaction will be something like the following: "This narrator claims to be telling a narrative based on reliable sources, but something seems to be wrong here, and therefore this cannot be accepted". To my mind, this is what happens in John 21:24-25. Let me point out some of the problematic aspects that will undermine the intended effect of the function of attestation in this case:

The identification of the Beloved Disciple as the real author of the narrative will come as a surprise to the implied reader - especially since there has been no indication thus far in the Gospel that there is any link between the Beloved Disciple and the narrator. If the Beloved Disciple is the real author of the narrative as the narrator, it would logically follow that the narrator should also be identified as the Beloved Disciple ${ }^{15}$. Thus far the narrator has constantly referred to the Beloved Disciple in the same way as to the other characters, namely in the third person - which may seem odd. Nevertheless, this could have been accepted by the implied reader as a stylistic idiosyncrasy or even a deliberate choice of the narrator to do it in this way. Even the sudden change from third person (Ov̂ं

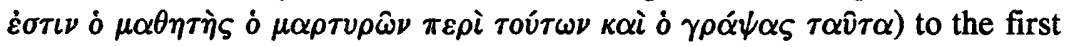
person (oi $\delta \alpha \mu \varepsilon \nu$ ) could have been understood by the implied reader as a result of the identification of the Beloved Disciple as the real author. However, what is inexplicable is that, even after referring to himself in the first person (oĽ $\delta \mu \varepsilon \nu$ ), three words further on the narrator still refers to the witness of the Beloved Disciple as "his" witness ( $\dot{\alpha} \lambda \eta \dot{\eta} \varsigma \alpha \dot{v} \tau o \hat{v})$. This, clearly does not make sense, since it should have been "my" or "our" witness. This is followed by another change that is inexplicable, namely from the first person plural (oí $\delta \mu \varepsilon \nu$ ) to the first person singular (oi $i \alpha u$ ). The implied reader would have expected either another plural form or, more naturally, a singular form in both cases. 
Thus it is clear that the function of attestation is fulfilled in a rather awkward way. This will undermine its intended effect. Instead of successfully convincing the implied reader of the reliability of the narrative, the way in which the narrator performs the function of attestation will force the implied reader to be suspicious, since the way in which this claim is worded does not make sense. Thus instead of immediately accepting the reliability of narrative the implied reader will be forced to ask questions. For example: Why does the narrator still keep his distance from the Beloved Disciple ("his" witness) after he switched to the first person ("we know")? Is this an indication that the narrator is not the Beloved Disciple? If so, how can the narrator's claim be accepted that the Beloved Disciple is the real author? Furthermore, does the change from first person plural ("we know") to first person singular ("I know") indicate a change in narrator? If so, does it also indicate a change in real author? If so, which parts of the narrative have been written by this (unknown) real author and which parts have been written by the Beloved Disciple? To all these answers the implied reader will find no answers, since none is given. The point is: In order to be effective, the function of attestation should be performed in such a way that the implied reader will not have the least doubt that the claim is valid. This does not happen in John 21:24-25, since it is worded in such a way that it will make the implied reader suspicious, forcing him/her to doubt its truthfullness.

To conclude: The tendency to interpret John 21:24-25 as a sophisticated and effective narrative technique is not correct. Narratologically, John 21:24-25 should be seen for what it is: A bold attempt at attestation that unfortunately has to fail, because it is performed in an awkward manner.

\section{NOTES:}

1 See for example, D A Carson, The Gospel according to John, Leicester 1991, 682-684 and L Morris, The Gospel according to John, London 1971, 879-882. For further discussion of this kind of approach, see $\mathbf{R}$ Kysar, "The Fourth Gospel in recent research", ANRW 25/3 (1985), 2436-2437.

2 Quite a variety of positions can be indicated in this regard. I mention only three to indicate the conflicting opinions of scholars on this issue: $\mathbf{M}$ Hengel, Die johanneische Frage. Ein Lösungsversuch. Mit einem Beitrag zur Apokalypse von Jörg Frey, Tübingen 1993, 224-225, 258, is of the opinion that John 21:24-25 were added by the final redactor(s) who put the finishing touches to the manuscript, but, nevertheless, ascribes the bulk of the Fourth Gospel to one person, the Beloved Disciple, who is identified as John the Elder. R E Brown, 
The Gospel according to John, London 1966, xxxiv-xxxix, limits the influence of the Beloved Disciple to the first two of a five stage development. According to Brown, op cit, 1126-1127, verses 24 and 25 were added together with the rest of John 21 by an editor during the fifth stage of development in order to claim that the Beloved Disciple "is the one who has borne the witness echoed in the written Gospel". W Schmithals, Johannesevangelium und Johannesbriefe, Berlin 1992, 215-259 who posits a hypothesis based on the assumed existence of a Grundevangelium (composed towards the end of the first century $A D$ ) that was reworked around $140 A D$ into a Gospel by a person with anti-gnostic sentiments, regards John 21:1-25 as part of a Lieblingsjüngerredaktion (around $180 A D$ ) during which substantial parts were inserted into the Gospel, thereby linking it to the apostolic authority of John, the son of Zebedee.

3 R A Culpepper, Anatomy of the Fourth Gospel. A study in literary design, Philadelphia 1983, 43-49.

4 Although Culpepper, op cit, 5-7, uses a modified version of S Chatman's narrative communication model (Story and discourse. Narrative structure in fiction and film, Ithaca 1978, 146-151) he defines the implied author not in the way it is done by Chatman, but follows W C Booth, The rhetoric of fiction, Chicago 1961, 72-74, who defines the implied author as an ideal version of the real author.

5 Culpepper, op cit, 47. It is important to note that Culpepper does not view John $21: 24$ as a sophisticated ploy of an individual author, since it problably came about as a result of later editorial activity.

6 J L Staley, The print's first kiss. A rhetorical investigation of the implied reader of the Fourth Gospel, Atlanta 1988.

7 See M Sternberg, Expositional modes and temporal ordering in fiction, Baltimore 1978, 279. Xenophon is cited as an example.

8 Since I have discussed the weak points in Staley's arguments elsewhere, I shall not repeat the arguments here. See my Jesus' farewell to the disciples. John 13:1-17:26 in narratological perspective, Leiden 1995, 51-57.

$9 \quad$ Staley, op cit, 115.

$10 \quad$ Ibid.

11 So too S van Tilborg, Imaginative love in John, Leiden 1993, 105-108, who prefers to use the term "explicit author".

12 For the arguments in this regard, see amongst others $\mathbf{R}$ Bultmann, Das Evangelium des Johannes, Göttingen 1941, 555; J Schnider, Das Evangelium nach Johannes, Berlin 1978, 334; R V G Tasker, John, Leicester 1983, 236; B 
Lindars, The Gospel of John, Eerdmans 1972, 641; E Haenchen, Das Johannesevangelium, Tübingen 1980, 592; J Kügler, Der Jünger, den Jesus liebte, Stuttgart 1988, 433; W Eckle, Der den Herr liebhatte - Rätsel um den Evangelisten Johannes. Zum historisches Verständnis seiner autobiographischen Andeutungen, Hamburg 1991, 61.

13 G Genette, Narrative discourse, Oxford 1980, 255-257. See also G Genette, Narrative discourse revisited, Ithaca 1988, 130-131.

14 With regard to the definition of the concepts "implied author" and "implied reader" I follow those narratologists who de-personify them and link them strongly to textual arrangement, for example Chatman, op cit, 147-150. The "implied author" should then be defined as the intratextual organising principle in the narrative text that is responsible for the overall organisation of the text, and the "implied reader" as the intratextual agent, functioning as its counterpart. For the difference between "implied author" and "implied reader", see Staley, op cit, 35 .

15 Technically it would be possible for an author to identify a character in the narrative as the real author without using this character as the narrator. See Chatman, op cit, 147. However, I think that such a sophisticated technique is more characteristic of modern literature. 